\title{
Pictures of Iowa in World War One (A Photo Essay)
}

\author{
George Mills
}

The fancy bar in Dubuque's Hotel Julien Dubuque (see cover) was turned into a Red Cross workshop office in the 1917-1918 war. Seated at left is Dubuque Red Cross Chairman J. K. Deming talking with Eleanor Connolly, director of county Red

Cross activities.

Thousands of Iowa Red Cross volunteers, wearing white uniforms, made more than 13 million surgical dressings that went to military hospitals and camps. They also made 1,249,000 hospital garments, 873,000 hand-knitted garments and other supplies. ${ }^{1}$ Workshops were set up in courthouses, city halls, schoolhouses, vacant storerooms, private homes, and at least one bar. ${ }^{2}$ Iowa sent 114,224 men and women ${ }^{3}$ into service, of whom 3,580 died. ${ }^{4}$

Many Iowans still spoke the German, Dutch and Scandinavian languages of their native lands. Governor William L. Harding decided this was a bad practice in wartime. He issued a proclamation forbidding the use of any language other than English in 
public places or over the phone. Acting Mayor C. W. Jacobs of Rock Valley, Iowa, issued his own proclamation calling attention to the Governor's edict. Harding also asked each lowa farmer to plant at least five acres of wheat to help alleviate the world bread shortage.

\section{A Proclamation}

To the People of Rock Valley:

Whereas, W. L. Harding, Governor of the State of Iowa, having issued by PROCLAMATION the following rules regulating the use of Foreign Languages; your attention is hereby publically called to same and you are earnestly requested to co-operate in this patriotic attempt to promote peace and harmony and to assist in the WINNING of the WAR by strictly observing these rules which should obtain in IOWA during the war:

1. English should and must be the only medium of instruction in public, private, denominational or other similar schools.

2. Conversation in public places, on trains and over telephones should be in the English language.

3. All public addresses should be in the English language.

4. Let those who cannot speak or understand the English language conduct their religious worship in their homes.

F. F. COCROFT, Clerk.

By Order of the Mayor

C. W. JACOBS (Acting)

Dated Rock Valley, Iowa, June 1, 1918. 


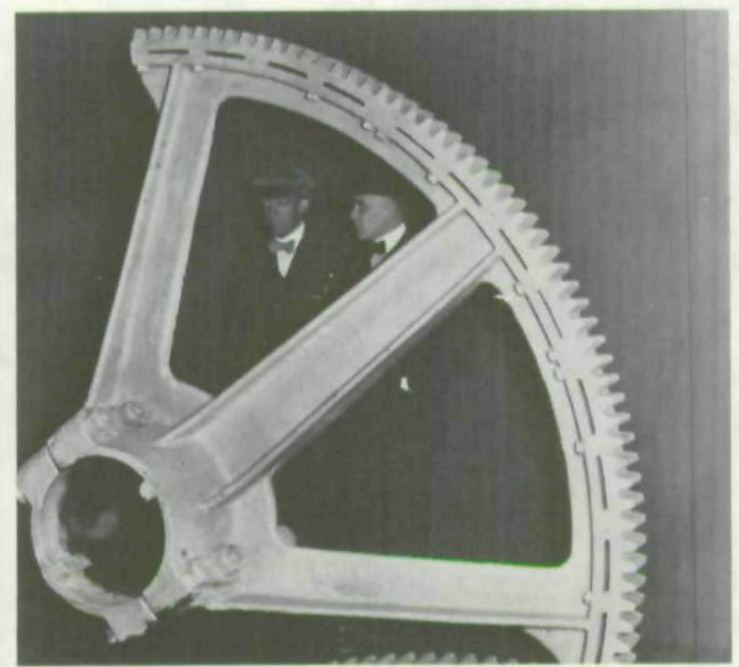

Iowa is far from the oceans, but Iowa industry contributed mightily to wartime shipbuilding. The Hart-Parr Company (now the White Farm Equipment Company) at Charles City manufactured this big quadrant for the steering engine of $a$ wooden ship in the emergency fleet.

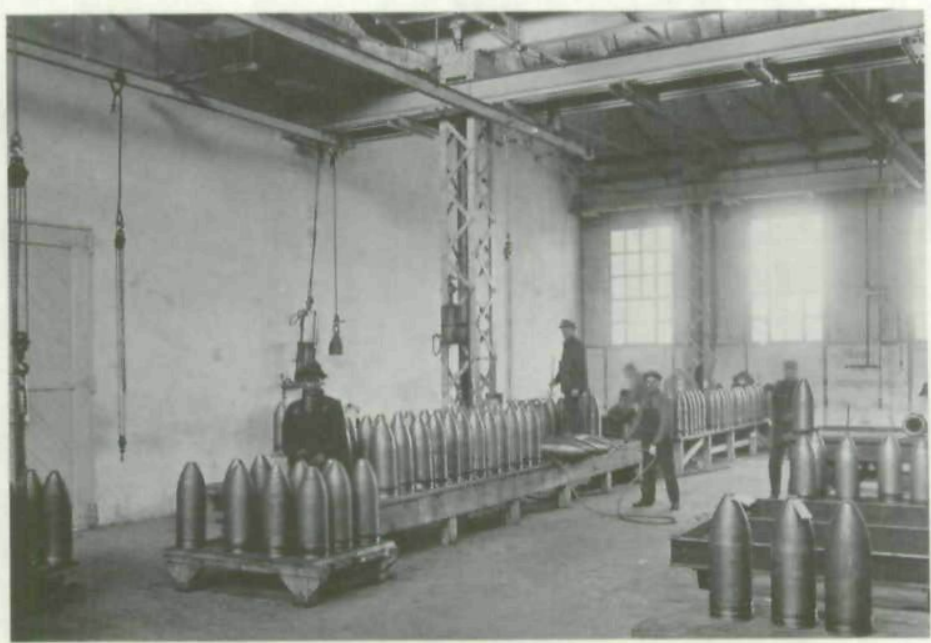

The Hart-Parr Company also manufactured shells for British howitzers. Great Britain and France were America's principal allies on the western front. 


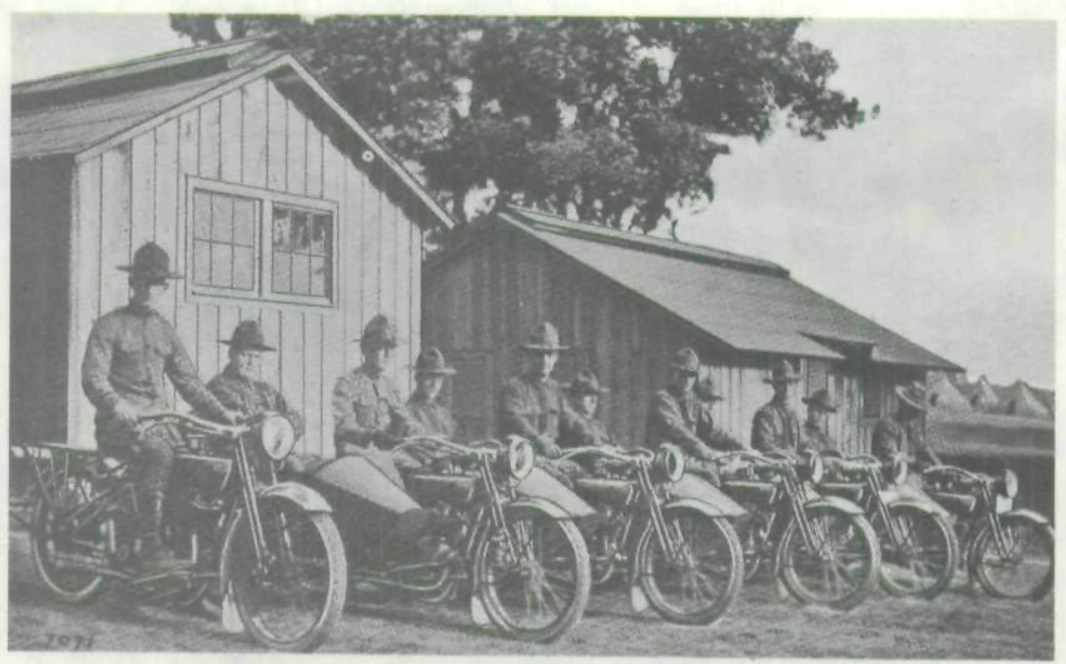

The "Motor-Cycle Brigade" carried dispatches at Camp Dodge, where more than 36,000 men were inducted into the armed forces. ${ }^{5}$ The camp, which is 12 miles northwest of downtown

Des Moines, was built in sixty days in 1917 at a cost of \$3.5 million. ${ }^{6}$

The first man to register at Camp Dodge in 1917 was 18-year-old George Whitmer. Whitmer later served as Mayor and on the City Council in Des Moines and now lives in retirement in Des Moines at 85 years of age. $^{7}$

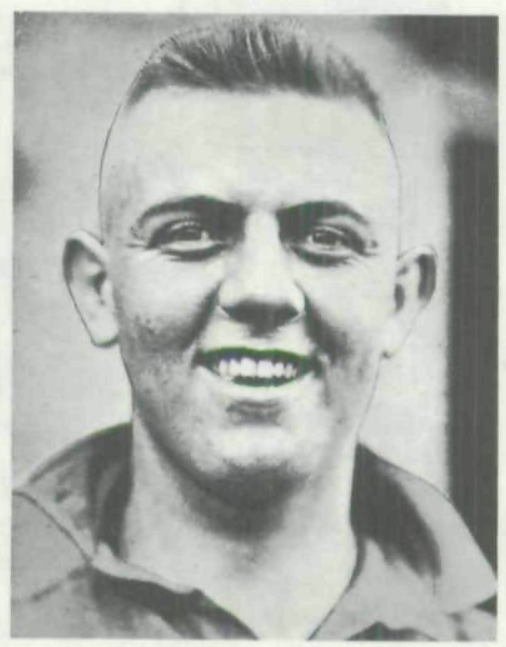




\section{Pictures of Iowa in World War One (A Photo Essay)}

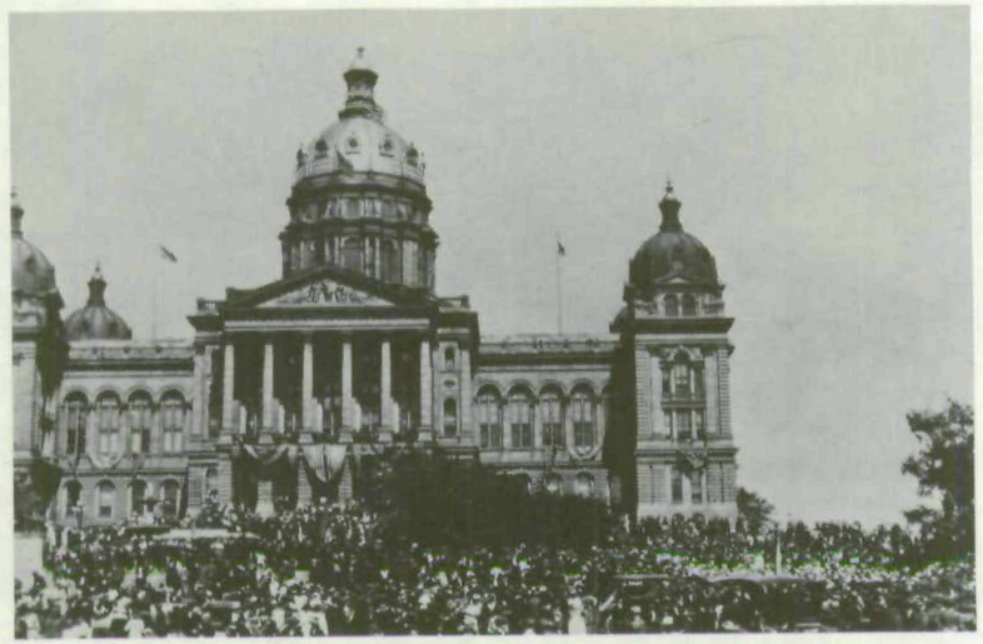

lowans went wild November 11, 1918 when Germany surrendered and ended the war. In Des Moines the "mad jubilation" presented a holiday scene " never equalled' in the history of the metropolis of Iowa. ${ }^{18}$ One of the largest crowds congregated on the west lawn of the Statehouse.

\section{Notes}

${ }^{1}$ Fulbrook, Earl S., The Red Cross in Iowa, State Historical Society of Iowa, 1922, Vol. 2, 23.

${ }^{2}$ Ibid., Vol. 2, 12.

${ }^{3}$ Iowa Official Register (1971-1972), 288.

"Swisher, Jacob, Iowa in Times of War, State Historical Society of Iowa, 110.

".Harlan, Edgar, The People of Iowa, Vol. 2, 302.

- Des Moines Register, "Our Sons at Camp Dodge," 1917, 1.

'Ibid., 1.

'Petersen, William J., The Story of Iowa, Lewis Historical Publishing Co., Inc., Vol. 2, 1002. 
Copyright of Annals of Iowa is the property of State of Iowa, by \& through the State Historical Society of Iowa and its content may not be copied or emailed to multiple sites or posted to a listserv without the copyright holder's express written permission. However, users may print, download, or email articles for individual use. 